\title{
Contextualizing "Practice": Helping Pre-Service Teachers Unpack the Ideological and Sociopolitical Dimensions of Required Practices for Licensure
}

\author{
Rachel Moody*
}

* Boston College, Department of Teaching, Curriculum, \& Society, Chestnut Hill, MA, United States

E-mail: rachel.moody@bc.edu

\section{Article Info}

Received: June 18, 2020

Revised: September 20, 2020

Accepted: September 25, 2020

\section{$10.46303 / j c s r .2020 .10$}

This is an Open Access article distributed under the terms of the CC BY 4.0 International license. (https://creativecommons.org/licenses/by/4.0/)

\section{How to cite}

Moody, R. (2020). Contextualizing "Practice": Helping Pre-Service Teachers Unpack the Ideological and Sociopolitical Dimensions of Required Practices for Licensure. Journal of Curriculum Studies Research, 2(2), 60-80. https://doi.org/10.46303/jcsr.2020.10

\begin{abstract}
The turn toward "practice" in teacher education, while controversial, has become a reality for many programs that prepare pre-service teachers for state licensure. This conceptual paper argues that while many people link teacher quality to educational equity, a focus on discrete teaching practices alone is insufficient to address inequitable outcomes in schooling. In addition to developing pre-service teachers to be critically conscious of the contexts in which their work is embedded, I contend that pre-service teachers may also benefit from contextualizing prescribed teaching practices themselves. Using examples from essential "elements" for teaching in the state of Massachusetts, I demonstrate two ways that required practices are themselves ideological and sociopolitical manifestations. By highlighting the ideological and sociopolitical discourse embedded within elements of effective teaching practice, teacher educators have the potential to prepare pre-service teachers to become critical consumers of practice.

\section{KEYWORDS}

teacher education, teacher practice, practice-based teacher education, sociopolitical context, teacher quality
\end{abstract}




\section{INTRODUCTION}

A focus on "practice"-broadly defined as instructional strategies or teacher moves-has returned to teacher education as a remedy to purported issues of teacher quality (Grossman \& Dean, 2019; Zeichner, 2012, 2016). Proponents of a focus on practice contend that improving teacher quality will lead to more equitable outcomes in schooling. This movement of sorts, although diverse in vision and enactment, has resulted in teacher preparation programming, coursework, and assessments that increasingly rely on the identification and acquisition of key knowledge (e.g. effective lesson design) and skills (e.g. how to facilitate a discussion). Whether described as "core practices" (Grossman, 2018), "high-leverage teaching practices" (Ball \& Forzani, 2011; TeachingWorks, n.d.) "techniques for champion teachers" (Lemov, 2010), or "instructional best practices" (Sposato Graduate School of Education, n.d.), the concept of "practice" has become firmly rooted in contemporary educational discourse.

Hotly debated by scholars, teacher educators, and policymakers, this return to practice is seen by many critics as a silver bullet solution that ignores the inherent complexity of our educational landscape (Bowman \& Gottesman, 2017; Crawford-Garrett \& Riley, 2019; Dutro \& Cartun, 2016; Kretchmar \& Zeichner, 2016; Philip et al., 2019; Zeichner, 2016). Further, skeptics doubt that the acquisition of teaching moves absent an understanding of this complexity leads to increased equitable outcomes. Even the strongest critics, however, do not eschew the concept of practice entirely. Some have argued that equitable teaching cannot occur without deep social, cultural, and historical knowledge of the contexts in which practice occurs (Bowman \& Gottesman, 2017; Kretchmar \& Zeichner, 2016; Zeichner, 2012, 2016). Zeichner (2016) advocated for a kind of "democratic practice", or "deliberation and collaboration across institutional structures" (p. 154). This strategy is used to model for pre-service teachers the ways that schools can work together with communities. Dutro and Cartun (2016) further, stressed the need to pay attention to bodies, affect, and power in complex moments of practice. They viewed the use of particular teaching practices as crucial, but added that pre-service teachers should also be "striving-imperfectly, but persistently - to be one on whom nothing is lost" (Dutro \& Cartun, 2016, p. 126). Finally, some critics have argued that without foundational knowledge of larger systems and trends (e.g. cycles of poverty, systemic racism), a focus on strategies alone limits what one can really "see" during any enactment of practice (Bowman \& Gottesman, 2017; Crawford-Garrett \& Riley, 2019; Philip et al., 2019). While the aforementioned scholars critique the ideas of locating practice at the "core," they nevertheless acknowledge that the practical matters of teaching represent a critical piece of a complex profession and field. In this paper, I further explore the rhetoric surrounding such practicalities as well as ways that teacher educators can infuse discussions of practice with appropriate complexity.

As scholars debate visions of teacher quality, the rhetoric of a focus on practice has simultaneously seeped into state policy. Indeed, Edward Crowe's vision for teacher accountability, outlined in the 2010 report by the Center for American Progress, has become a 
reality in most states' teacher evaluation and licensure systems. As states become increasingly concerned with evaluating "pupil learning results or other outcome measures" (Crowe, 2010, p. $5)$, they have more narrowly focused on the teaching practices that they believe produce those outcomes. In Michigan, for example, value-added measures of teacher effectiveness have been phased into evaluation systems and the Michigan Department of Education has heavily invested in the utilization of TeachingWorks' 19 "high-leverage" teaching practices in their preparation programs (Michigan Department of Education, n.d.) ${ }^{1}$. Although value-added measures are no longer used for evaluation in the state of Massachusetts, a focus on practice is nevertheless baked into program requirements in the form of "essential elements of practice for novice teachers" (Massachusetts Department of Elementary and Secondary Education, 2016, p. 5). As state officials attempt to isolate the variables (in the form of teaching moves) that produce effective instruction, many preparation programs must increasingly focus on practice regardless of institutional goals and visions.

Like those featured above, I echo the sentiments of teacher educators and scholars who posit that a focus on practice alone is insufficient to address issues of equity and opportunity in education. This paper argues that pre-service teachers may additionally benefit from a rich contextualization of required teaching practices themselves. Using the term, "contextualization," I signal the unpacking of individual teaching practices in order to identify from where and whom they have emerged. As I will show, education stakeholders construct seemingly objective criteria for effective instruction while operating from specific ideological and sociopolitical positionings. Instead of isolating ideological and sociopolitical topics within social foundations coursework (e.g. "Democracy and Equity in Education"), I, and others, propose that teacher educators take up these topics with pre-service teachers as we engage in practical conversations of what "good" teaching looks like (Milner IV, 2010; Nieto, 2000). To illustrate this process, this paper draws upon required teaching practices for Massachusetts state licensure. Although the focus of my analysis is limited to one state, my interrogation of practice discourse in Massachusetts will likely resonate elsewhere.

In the section that follows, I provide further details about this contextualization process, including a rationale and examples of scholars already engaged in similar work. I also expand upon my own context and make a case for utilizing discourse from Massachusetts as an example of stakeholders' discursive construction of teaching practice writ large. In the second part of the article, I draw upon personal experience and relevant literature to illuminate ways in which teacher educators might critically interrogate practice discourse with pre-service teachers as they learn to teach. Specifically, I detail my exploration of Massachusetts's descriptors of "WellStructured Lessons" and "High Expectations," two of the state's elements of effective teaching practice for licensure. The article concludes with a call to continue to find ways to develop pre-

\footnotetext{
${ }^{1}$ In 2018-19, the Michigan Department of Education (MDE) required that 25\% of teacher and administrator evaluations be based on student growth (value-added) measures. In the 2019-20 school year, MDE required $40 \%$ of evaluations be based on student growth. (https://www.michigan.gov/mde/0,4615,7-140-5683 $7543878528---, 00 . h t m l$ )
} 
service teachers' professional judgment, manifested in their ability to become critical consumers of practice.

\section{CONTEXTUALIZING REQUIRED TEACHING PRACTICES}

There is significant debate about the kind of teacher quality that is required to help achieve equitable outcomes in schooling. Universities have been criticized for doing too little to prepare pre-service teachers for the practical matters of the classroom (Ball \& Forzani, 2009; Grossman et al., 2009; Zeichner, 2012). Driven by federal mandates (e.g. No Child Left Behind, Every Student Succeeds Act), select scholarship on the importance of practice in teacher education (e.g. Ball \& Cohen, 1999; Ball \& Forzani, 2009; Grossman et al., 2009; McDonald et al., 2014; Thompson et al., 2013), and "research-based" teaching strategies (e.g. What Works Clearinghouse), leaders have begun to define quality teaching at the state level. Some states, such as Michigan and Massachusetts, have further infused this vision into requirements for teacher preparation programs.

Manifested within these practices are specific ideologies of teaching and learning along with signals of larger sociopolitical trends in education and society. Pre-service teachers focused on acquiring specific skills for licensure may miss out on these larger references and debates. If teacher educators want teachers that are not only skillful practitioners, but who also know how their teaching practices position them within the field of education, we must let them in on larger debates surrounding practice. In other words, pre-service teachers can become attuned to deeper meanings embedded in practice as they practice teaching. This integrated approach is rooted in a vision of teaching as a complex intellectual, political, and practical professional that involves careful decision-making (Cochran-Smith \& Lytle, 2006). Cochran-Smith \& Lytle (2006) asserted that "rather than a process of using strategies certified by so-called scientifically based research, teaching requires the intentional forming and re-forming of frameworks for understanding practice" (p. 691). Through an unpacking of discourse and reflections on my own experiences teaching, this paper identifies some ways that teacher educators can engage preservice teachers in this formation process.

Although there are many dimensions of practice that could be explored, I examine two: underlying ideologies of teaching and learning and sociopolitical discourse manifested in individual practices. First, I focus on ideologies of teaching and learning due to the significant shifts in the ways that scholars have studied and conceptualized what it means to know and learn over the last few decades. In Kolodner's (1991) opening editorial of the first issue of The Journal of the Learning Sciences, she declared that although there were many theories of teaching, those in education "[did] not have sufficiently concise theories of learning to be able to tailor the curricula to the natural way kids learn" (p. 1). At the time, Kolodner was speaking to the ways in which cognitive science could play a role in education, but the research on learning has since been undertaken by scholars with diverse orientations and backgrounds 
(Yoon \& Hmelo-Silver, 2017). Scholars in the learning sciences now know that depth of understanding is more important than coverage of topics; students must actively engage in their own learning; teachers should draw upon students' prior knowledge; and students benefit from metacognitive awareness of the learning process (Bransford et al., 2000; Sawyer, 2014). Many also understand that culture and identity play a large role in students' understandings of content and engagement in classrooms (Gutiérrez \& Rogoff, 2003; Lee, 2017; Nasir et al., 2014; Sfard \& Prusak, 2005). Pre-service teachers deserve to know how required practices reflect (or do not reflect) these evolving understandings of what it means to know and learn.

Pre-service teachers may also benefit from understanding how individual practices can reflect larger sociopolitical trends in education-messages which are perhaps more difficult for beginning teachers to locate themselves. Nasir et al. (2016), for example, spoke to the frequent absence of sociopolitical context in research on teaching and learning. This paper aims to address that gap. Nasir et al. (2016) further highlighted the ways in which stakeholders utilize sociopolitical frames to "shape norms, attitudes, and beliefs about what constitutes equitable teaching, what equitable schools look like, and which practices such schools should emphasize in their daily work" (p. 356). Stakeholders that believe in the frame of meritocracy, for example, may push for equity via educational efficiency. "Equitable" schools in this scenario, might separate students by (perceived) ability in an effort to tailor instruction to individual needs (i.e. tracking) (Anderson \& Oakes, 2014; Lucas, 1999). This common sense approach, although hotly debated, is thought to result in increased achievement for all students (Hallinan, 1994). Teachers are then guided toward specific practices for different levels, often resulting in higherorder creative tasks for higher tracks and simple recall tasks or test preparation for lower tracks (Oakes, 2005; Watanabe, 2008). In this example, the frame of meritocracy has been effectively mobilized toward a specific school structure and corresponding teaching strategies. If teacher educators attempt to deconstruct other popular instructional strategies, they might similarly uncover specific sociopolitical frames underlying the rationales for such approaches. This contextualization process might also help pre-service teachers discern whether seemingly equitable approaches match their own definitions of educational equity.

Recent scholarship has similarly attempted to locate ideological and sociopolitical discourse embedded in popular approaches to teaching. Dutro and Cartun (2016), for instance, explored ideological discourse emerging during enactments of instructional routines for writing. Specifically, the authors helped pre-service teachers look at student affect as a way to highlight "discourses of control and failure in teaching and learning" (p. 124). Both Crawford-Garrett and Riley (2019) and Sheth (2018) have engaged in the identification of sociopolitical frames embedded in best practices in their content areas. Crawford-Garrett and Riley (2019) intentionally addressed the need to "[help] pre-service teachers recognize how daily practices are bound up within broader discourses" (p. 43). In their study linking knowledge of endemic poverty and equitable assessment in literacy, the authors consistently asked pre-service teachers to examine this discourse and consider "how particular practices can both promote 
and undermine efforts towards educational equity" (p. 46). Additionally, Sheth (2018) located the frame of colorblindness in Windschitl et al.'s (2012) strategies for "ambitious science teaching". Her study found that colorblind teaching practices served to flatten the racialized experiences of students in science classrooms She proposed "grappling with racism as a foundational practice that provokes teachers to critically engage with...contradictions that emerge from racism manifested in science and science teaching to make principled decisions that disrupt persistent unequal relations of power" (p. 55). In summary, the aforementioned scholars argued that students benefit from having teachers who have critically interrogated the complexity of any instantiation of "effective" teaching practice.

These authors, however, have mostly questioned the use of best practices in different content areas. I specifically focus my questions on Massachusetts state policy surrounding effective practice and draw from my own experiences working with beginning pre-service teachers in the licensure process. Massachusetts is unique in that it is consistently looked to as having the best public schools in the United States (U.S. News \& World Report, 2020). Scoring exceptionally well on standardized tests such as the NAEP, Massachusetts has historically led the way in embracing high standards and accountability structures (Chieppo \& Gass, 2009; Wong, 2016). As such, the state was also an early adopter of performance assessments used to measure the readiness of pre-service teachers. As other states are now just beginning to adopt similar assessments (e.g. edTPA), Massachusetts has spent years developing and implementing their own home-grown version. The Candidate Assessment of Performance, or the CAP, identifies effective teaching practices, or "elements," and is purportedly better aligned to Massachusetts standards for the teaching profession (Massachusetts Department of Elementary and Secondary Education, 2016). Because Massachusetts has identified specific practices to help pre-service teachers be ready "on day one," (Massachusetts Department of Elementary and Secondary Education, 2016), it is a ripe context for the application of my pedagogical approach. As a trailblazer in education policy, Massachusetts's focus on practice may additionally be emblematic of future policy trends across the U.S. In the following two sections, I examine discourse from two teaching elements from the Massachusetts CAP, "WellStructured Lessons" and "High Expectations," in order to illustrate how one might do the work of contextualizing required practices with pre-service teachers.

\section{UNPACKING THE “WELL-STRUCTURED LESSONS” TEACHING ELEMENT}

Although there are six required teaching elements in Massachusetts ${ }^{2}$, this paper will focus on two in order to demonstrate ways to contextualize practice with pre-service teachers. The first

\footnotetext{
${ }^{2}$ Required elements include "Well-Structured Lesson," "Adjustment to Practice," "Meeting Diverse Needs," "Safe Learning Environment," "High Expectations," and "Reflective Practice." The list of elements and their descriptors were updated in August, 2019 to include an additional element ("Subject Matter Knowledge") and some revised language. In this paper, however, I am using the 2016 list of elements as preparation programs are not yet required to utilize this revised version (see Massachusetts Department of Elementary and Secondary Education, 2019).
} 
element I explore, "Well-Structured Lessons" (Figure 1), was designed as part of the larger "Curriculum, Planning, and Assessment" standard. Embedded within each descriptor of proficient practice are obvious and less explicit referents to sociopolitical frames and visions of teaching and learning. There are numerous ways to draw out these contextual features, thus, the examples I provide are not exhaustive. For the purposes of this paper, I specifically focus on one phrase in the "Well-Structured Lessons" descriptor: "challenging, measurable objectives." I utilize this discourse to highlight some questions and topics that one could use to help preservice teachers both understand what they're being asked to do and critically examine whether and how to do it.

Figure 1

Well-Structured Lessons Element Descriptor

\begin{tabular}{|l|l|}
\hline Element & Proficient Descriptor \\
\hline 1.A.4: & Develops well-structured lessons with challenging, measurable objectives \\
Well- & and appropriate student engagement strategies, pacing, sequence, actiities, \\
Structured & materials, resources, technologies, and grouping. \\
Lessons & \\
\hline
\end{tabular}

Note. Table reproduced from the Guidelines for the Candidate Assessment for Performance (Massachusetts Department of Elementary and Secondary Education, 2016)

\section{"Challenging, measurable objectives" in Policy and Practice}

The use of "backward design" (Wiggins \& McTighe, 2005) and the revised Bloom's Taxonomy (Anderson et al., 2001; Krathwohl, 2002), originally called The Taxonomy of Educational Objectives, have become ubiquitous in teaching and teacher education (Cho \& Trent, 2005; Peltier \& Noonan, 2003; J. Schneider, 2014). The two are used in tandem so frequently that Wiggins and McTighe's (2005) Understanding by Design advocated for the use of the revised Bloom's Taxonomy in its introductory chapter. When pre-service teachers are asked to develop "challenging, measurable objectives" as part of lesson planning, they are being asked to engage in the backward design process. This process involves determining learning objectives and related assessments prior to teaching a lesson. Objectives are derived from larger unit or course goals ("Enduring Understandings" or "Big Ideas") as well as state content standards (Wiggins \& McTighe, 2005). To make sure objectives are appropriately "challenging," pre-service teachers are regularly asked to refer to Bloom's in order to choose a verb that describes the type of thinking that students will be doing during the lesson. Although not explicitly stated in the CAP's descriptor for "Well-Structured Lessons," both backward design and the revised Bloom's Taxonomy are commonly used by preparation programs to meet such visions of effective practice. Indeed, in all four institutions where I have supervised or taught pre-service teachers in Massachusetts, required lesson plan templates align with these approaches. At one institution, for example, pre-service teachers are asked to create objectives and assessments 
that align to larger state curriculum standards and the "big picture" of student learning (Figure 2).

\section{Figure 2}

One Institution's Required Lesson Plan Template

\begin{tabular}{|l||}
\hline \multicolumn{1}{|c|}{ OVERVIEW OF THE LESSON } \\
\hline $\begin{array}{l}\text { MA Curriculum Frameworks: With regard to how this lesson fits into the "big picture" of the } \\
\text { students' long-term learning, which MA framework does the lesson most clearly address? }\end{array}$ \\
$\begin{array}{l}\text { Instructional Objective: By the end of the lesson, (1) what concept, information, skill, or } \\
\text { strategy will the student(s) learn and (2) how will they demonstrate that knowledge? }\end{array}$ \\
Assessment: What specific, tangible evidence will show that each student has met this \\
objective?
\end{tabular}

Note. This template was publicly available via online Google search (Boston College, 2013)

To complete this template, one of my supervisees wrote the following learning objective: "Students will be able to classify four-sided shapes as rectangles or other quadrilaterals." Here, this pre-service teacher utilized the verb "classify," which is drawn from the lower part of the Bloom's triangle (Figure 3). Not surprisingly, I had not prepared this teacher to draw upon Bloom's in this way. Before working together, they were already familiar with the process of creating "challenging, measurable objectives" via other coursework and practicum experiences. This instructional planning example, thus, highlights the degree to which Massachusetts guidelines for effective instruction are paralleled in many institutions' program design features.

\section{Figure 3}

\section{Bloom's Taxonomy Triangle}

\section{Bloom's Taxonomy}

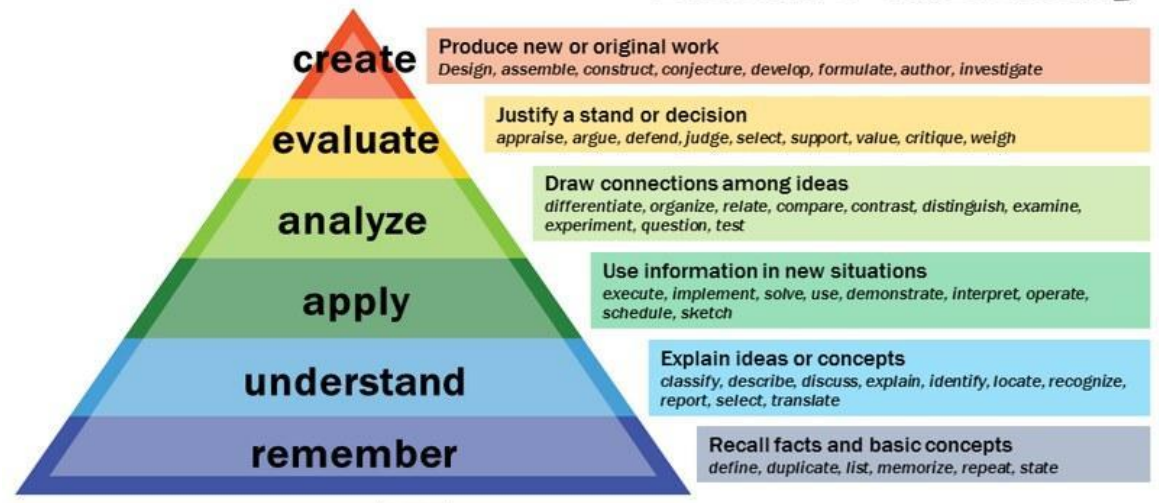

Note. Image licensed under a Creative Commons Attribute and retrieved from the Vanderbilt University Center for Teaching website (Armstrong, n.d.) 


\section{Questioning the Role of the Teacher in Instructional Planning}

As we consider the popular instructional approaches reflected in state directives (such as using "challenging, measurable objectives"), it is important that teacher educators raise questions about their affordances and limitations. Approached uncritically, pre-service teachers may not realize that nearly all aspects of curriculum design are debated. In fact, some scholars who advocate for the use of inquiry- or project-based approaches to teaching, reject the idea that all learning outcomes be predetermined by the teacher (Blumenfeld et al., 1991; File et al., 2012; Schneider et al., 2002; Singer et al., 2000). Dewey (1959) argued that when students are engaged in an inquiry process, they are more intrinsically motivated and gain deeper understandings of material. In phenomenon-based science teaching, an approach rooted in student inquiry, teachers and students engage in a process of collectively formulating questions in order to investigate a particular scientific phenomenon (Next Generation Science Standards, 2016). The teacher understands the components of the phenomenon in order to nudge students in a particular direction, if necessary, but students are often responsible for identifying which topics surface at which times. Inquiry thus, involves students in directing the content and flow of discussion. This is a more constructivist approach to teaching and learning, while the language of "Well-Structured Lessons" more closely resembles teacher-directed learning.

In my own classes with beginning pre-service teachers, we critically examine required lesson plan templates. These templates differ slightly across institutions, but all reflect a standard backward design process. I first gauge my students' initial assumptions about planning and their reactions to the lesson plan format. We then co-construct our class objectives for learning about lesson structure. This approach accomplishes two goals. First, our instructional objectives emerge from where students are beginning and what they are interested in. Second, my modeling of a more constructivist approach to lesson design serves as an opportunity for critique and comparison via meta-analysis. In this example, beginning pre-service teachers are presented with alternatives to "normal" backward design processes, and are, thus, treated as discerning consumers of practice. By engaging in conversations about the pros and cons of student- and teacher-centered instruction, they are allowed to consider the philosophical, moral, and practical implications of their work.

\section{Sociopolitical Debates : Predetermined Objectives and Measurement of Learning}

Embedded within the short phrase "challenging, measurable objectives" are also referents to sociopolitical discourse and historical trends in education. Although "measurable" may immediately appear to education scholars as a loaded term, this is likely not the case for preservice teachers. Thus, pre-service teachers may benefit from unpacking the concept of measurement with teacher educators as they learn to measure what students produce.

In their early conception, measurement practices in education were used as mechanisms for determining who was capable of learning. Although this practice continued for many years (see Larry P. v. Wilson Riles), the purpose of measurement shifted as the field of curriculum and 
instruction emerged in the early- to mid-20th century. Measurement was now seen as a mechanism for educational improvement by a growing camp of educational researchers focused on child and human development (Lagemann, 2000). In 1949, Ralph Tyler, a member of this developmentalist camp, published his famous text Basic Principles of Curriculum and Instruction, in which he stated that the formulation of objectives (and corresponding assessments) was crucial for effective instruction. Interestingly, Wiggins and McTighe (2005) (who are scholars in the field of educational measurement) credited "the logic of backward design" to Tyler in the first chapter of Understanding by Design (p. 20). In my discussions of practice with pre-service teachers, we consider how the purposes of education evolved alongside testing and measurement practices. As momentum shifted in favor of increased educational access, curriculum and instruction scholars "wanted to improve the effectiveness of instruction, rather than perfecting instruments of selection" (Lagemann, 2000, p. 157). Measurement, then, could be used to help tailor instruction to increasingly diverse groups of students.

Today, the effects of measurement in education are widely contested. Cho and Trent (2005) argued that a focus on predetermined objectives and their corresponding assessments align neatly with larger accountability practices in education. The process of designing curriculum "backward" "fulfill imperative needs of stakeholders facing standards, assessment, and accountability measures resulting from the No Child Left Behind Act" (Cho \& Trent, 2005, p.105). Nasir et al. (2016) further posited that measurement practices in education reflect the neoliberal values of "competition, productivity, and efficiency" (p. 359) and that "public education's heavy reliance on high-stakes, standardized testing, data-driven decision-making, technology, objectives-based planning, performance monitoring, and curricular alignment reveals the depth with which schools and districts mediate these institutional trends" (p. 359). Implicit in such market-oriented approaches to education is the idea that tight control and measurement of instructional practices will result in high academic achievement for all students. The presupposition underlying this assumption is that teachers can create the conditions for educational equity. Another presupposition is that increased academic achievement (likely measured via standardized test scores) will translate to a more equitable distribution of our society's resources. When discussing this idea with pre-service teachers, it is important that they understand that teaching-centered approaches to educational equity are debated. Cochran-Smith et al. (2016), for example, saw such approaches as overly simplistic, or "thin" attempts to increase equity. These authors wrote:

When policies work from a thin equity perspective, the assumption is that school factors, particularly teachers, are the major source of educational inequality and that access to good teachers is the solution to the equity problem. This viewpoint ignores the fact that teachers account for a relatively limited portion of the overall variance in student achievement, and it does not acknowledge that inequality is rooted in and sustained by 
larger, longstanding, and systemic societal inequalities. (Cochran-Smith et al., 2016, p. 5)

By investigating this tension, pre-service teachers learn how "good" instructional practices can be mobilized by state officials and practice-focused scholars as silver bullet solutions to problems of educational equity. If instructors present pre-service teachers with these tensions related to instructional measurement, they not only learn where a focus on measurement comes from, but can develop a more well-rounded view of what their teaching practices can realistically accomplish.

\section{UNPACKING THE “HIGH EXPECTATIONS” TEACHING ELEMENT}

Students come to school with varying levels of preparation, interest, and success in different content areas. A perennial challenge for teachers is figuring out how to set realistic, but challenging goals for student outcomes. This is especially difficult for pre-service teachers. Education stakeholders regularly attribute student success to the expectations teachers hold for them. Phrases such as having "high expectations for all students" are ubiquitous in everything from school promotional materials to national governing agencies' websites. Many charter school leaders, for example, believe that "high expectations are the most reliable driver of high student achievement" (Lemov, 2015, p. 89). But what exactly is meant by "high expectations"? This seemingly common sense phrase is laden with assumptions about teaching and learning and has been historically mobilized toward sociopolitical ends. As teacher educators talk to preservice teachers about their expectations for students, it may be beneficial to deeply contextualize the usage of this common rhetoric.

In this section, I explore the required element of practice, "High Expectations." This element comes from the CAP's "Teaching All Students" standard and asks pre-service teachers to facilitate students' mastery of content by emphasizing the importance of "effort," rather than "innate ability" (see Figure 4). In order to explore concepts that influence teacher expectations, I specifically focus on the juxtaposition of "effort" and "innate ability" used in this element. I also delve into the historical usage and contemporary debates surrounding "high expectations" for student effort and performance.

Figure 4

High Expectations Element Descriptor

\begin{tabular}{|l|l|}
\hline Element & Proficient Descriptor \\
\hline $\begin{array}{l}\text { 2.D.2: } \\
\text { High Expectations }\end{array}$ & $\begin{array}{l}\text { Effectively models and reinforces ways that students can master } \\
\text { challenging material through effective effort, rather than having to } \\
\text { depend on innate ability. }\end{array}$ \\
\hline
\end{tabular}

Note. Table reproduced from the Guidelines for the Candidate Assessment for Performance (Massachusetts Department of Elementary and Secondary Education, 2016) 


\section{The Juxtaposition of "Effort" and "Innate Ability"}

Scholars, policymakers, and educators have long tried to distill the elements that produce academic success. In particular, many believe that teachers' expectations of students influence schooling outcomes. The logic goes that if teachers set high goals and provide appropriate supports, any student is capable of growth. This refutes the common rhetoric that some people are "born smart."

Although educators likely believe that they are communicating the importance of effort to students, schools also communicate many messages about "innate ability." In my own classes, for example, pre-service teachers who regularly applaud the efforts of their hard-working students also utilize evaluative labels when discussing their (perceived) abilities. This phenomenon is not surprising given that by the time pre-service teachers arrive in their teaching programs, they have already experienced years of formal evaluation in the form of grades, test scores, and admissions processes. Many have internalized the results of these evaluations as hard-and-fast judgments of their (innate) abilities. Thus, I first use the "High Expectations" element as an opportunity to unpack ideas with them related to fixed intelligence, or ability.

Many people wonder how to define intelligence and whether it can be measured. With my own students, I have explored these questions using the case study of Larry P. v. Wilson Riles. The popular Radiolab podcast, "The Miseducation of Larry P.," (Lee, 2019) profiled the elementary school experiences of a Black student in the 1970s who was segregated into special education classes after receiving a low score on an IQ test. At the time, IQ tests were regularly used in schools as determinants of students' overall academic abilities (Lee, 2019). The podcast described how "Larry's" (a pseudonym) case led to the eventual banning of IQ tests for Black children in California. Interestingly, it also revealed that the original creator of the IQ test never meant for it to be a determinant of fixed ability. This revelation, along with the podcasters' detailed content analysis of IQ test items, helped my students problematize the universality of standardized measures of intelligence. The podcast let us examine our own constructed notions of intelligence and then begin to consider this concept's relationship to effort and growth.

The relationship between effort and growth, however, also deserves attention. All educators acknowledge that some students struggle academically. A critical question, then, is whether or not students can grow academically through "effective effort." By juxtaposing student effort and ability, the CAP's "High Expectations" element highlights this larger tension.

Although teachers' ideas about the influence of effort on student achievement may vary, many have been influenced by the popular concept of "growth mindset" (Dweck, 2007). Dweck's (2007) work on mindset has been widely adopted in educational settings around the world. The concept of "growth mindset" is rooted in the belief that like a muscle, intelligence or skillfulness can grow with practice. Those with a growth mindset seek out feedback and new ways of approaching difficult tasks because they believe improvement is possible. People with a "fixed mindset," on the other hand, are more likely to believe that they are just not good at a 
particular skill and give up. Educators, upon learning that Dweck's notion of intelligence defied conventional wisdom around innate ability, flocked to this concept for its applicability with struggling learners. When the Massachusetts CAP references a focus on "effort," rather than (perceived) ability, it is likely drawing upon this perspective.

Pre-service teachers should consider, however, that shallow uptakes of "growth mindset" can result in a sole focus on student effort, persistence, or "grit" (Duckworth, 2018; Duckworth et al., 2007). As Dweck (2015) noted upon reflecting on her work years later, a common misconception is that individual growth happens solely through increased effort. She wrote:

Certainly, effort is key for students' achievement, but it's not the only thing. Students need to try new strategies and seek input from others when they're stuck. They need this repertoire of practice-not just sheer effort - to learn and improve. (Dweck, 2015) Just as pre-service teachers problematize what it means to be smart, they must also carefully examine how student growth occurs. If teacher educators do not facilitate this investigation, pre-service teachers may fall back on traditional beliefs that improvement happens through "sheer effort" (Dweck, 2015). Similarly, if pre-service teachers maintain uncomplicated notions of fixed intelligence, it may result in superficial attempts at promoting student effort. In other words, one has to believe that it is possible to grow and understand academic growth in order to hold high expectations of others. Thus, as teacher educators push their pre-service teachers to hold high expectations for all students, they may find it useful to unpack internalized beliefs around "effort" and "innate ability."

\section{The Sociopolitical Framing of "High Expectations"}

When using "high expectations" as a model of effective practice, it is also important that preservice teachers be given the opportunity to learn about the historical legacy and continuing debates around "high expectations" rhetoric. This rhetoric includes the placing of sole responsibility for educational outcomes on teachers and the ideologies mobilized in support of an emphasis on student effort. By unpacking the sociopolitical underpinnings of this discourse, teacher educators can help pre-service teachers better navigate their roles in schools and society.

\section{The Influence of "High Expectations" on Educational Outcomes}

Although neoliberal reformers and progressive educators often disagree on pathways to educational equity (and, sometimes, definitions of "equity"), their beliefs in the power of teacher expectations are often aligned. The focus on teacher expectations in education has existed for decades. In 1979, Ron Edmonds wrote his famous appraisal of effective and ineffective schools and in reviewing the research found that "urban schools that teach poor children successful have strong leadership and a climate of expectation that students will learn" (p. 15). This represented an early vision of equitable schooling practices. In 1999, George W. Bush mobilized the language of "high expectations" to push for neoliberal reforms. As governor of Texas, he wanted stronger testing and accountability measures for schools and teachers. In 
his now famous speech, Bush warned that resistance to high standards and measurement represented "the soft bigotry of low expectations" ("Excepts from Bush's speech on improving education, 1999).

When Bush passed the No Child Left Behind Act in 2002, the use of testing and educational standards became widespread in the United States. As standardized testing confirmed the persistence of achievement gaps based on income and race, the language of "high expectations" returned. Many progressive educators and scholars have since rallied in response to these gaps, also stressing the need for high(er) teacher expectations for student achievement. Although their underlying motives may differ from those of neoliberal reformers, they send similar messages about the degree to which teachers bear responsibility for equitable outcomes in education. Gershenson and Papageorge (2018), for example, examined the degree to which a teacher's race influences their expectations of Black students and how these expectations influence educational trajectories. Their analysis of data from the Educational Longitudinal Study of 2002 revealed that "black students do not receive the same positive bias enjoyed by white students" (p. 69) when White teachers predict their likelihood of attending college. Whether this practice is rooted in beliefs of racial superiority or an understanding of the systemic barriers that Black students face, the net result was a self-fulfilling prophecy of lower educational attainment. Delpit (2012) and Sleeter (2008) similarly emphasized the influence of teacher expectations on student success. Delpit (2012) rejected the idea of an achievement gap, insisting instead on the existence of an "expectations gap" in our schools. Sleeter (2008) called for the diversification of the teaching force to combat the low expectations of White teachers. The volume of such rhetoric, thus, implies that teachers are a major contributing factor to educational inequity.

Some scholars disagree, however, with placing the sole responsibility of educational equity on the shoulders of teachers. Nieto (2010), for example, acknowledged the harmful outcomes correlated with individual teacher's low expectations, but argued that these expectations are small-scale manifestations of larger issues in our society. She wrote that "the use of the term teachers' expectations distances the school and society from their responsibility and complicity in student failure" (p. 59). As mentioned earlier, Cochran-Smith et al. (2016) also questioned stakeholders' overreliance on aspects of teacher quality to produce equitable outcomes in schooling. They argued that a focus on teachers is not only inaccurate, but, as Nieto (2010) asserted, conveniently puts the onus on individuals to change instead of larger systems and institutions.

This debate over the responsibility of teachers in student outcomes presents another opportunity for teacher educators to delve further into the complexity of common educational rhetoric. It is clear that teacher expectations matter, but can "high expectations," or teachers alone, achieve the kinds of outcomes stakeholders seek? These are critical questions to unpack with pre-service teachers as they begin to internalize their roles as society's change makers. 


\section{The Emphasis on Individual Effort in Promoting Academic Achievement}

Finally, the language of the Massachusetts CAP requires pushing students to meet high expectations through "effective effort." Because so many educators draw on the logic of "effort" to encourage a growth mindset, it is important to discuss the implications of a focus on effort with pre-service teachers. As previously noted, equating effort with growth mindset is an overly simplistic interpretation of the concept. Instead, their emphasis on growth through effort alone is more aligned with Duckworth et al.'s (2007) conception of "grit." Duckworth et al. (2007) defined "grit" as "perseverance and passion for long-term goals" (p. 1087). People who have a lot of grit persist despite challenges, setbacks, and adversity.

An explicit focus on grit, or a focus on grit masked as growth mindset, is a feature of many schools and programs aimed at achieving equity through increased student achievement. It is unlikely, however, that pre-service teachers understand this concept's link to meritocratic ideals of education. Meritocratic framing locates the root of educational failure within the individual and ignores "systematically rooted systems of marginalization and oppression" (Nasir et al., 2016, p. 352). If a student fails, it is because they did not sustain enough effort, or persist in pursuit of long-term goals. This framing becomes particularly problematic when "grit" is mobilized in contexts with students who already face significant challenges within and outside of school. Strauss (2016) argued that by virtue of having to navigate the daily challenges of poverty, low-incomes students already have sufficient grit. Love (2019) further noted that Black communities have survived generations of oppression and asked, "Is this not grit?" (p. 85). Both authors agreed that the reliance on effort through the lens of meritocracy did not accurately represent the realities of the complex, inequitable systems affecting students' lives. A sole reliance on individual effort, then, has the potential to further marginalize students who are already battling the effects of multi-systemic oppression.

As I contextualize the discourse surrounding academic expectations, I do not mean to imply that teachers should hold low expectations for students who face challenges. Locating the sociopolitical controversies in such common-sense statements like "high expectations," however, may help pre-service teachers more critically consider their own expectations for students. Regardless of the exact language of the CAP, pre-service teachers stand to benefit from considering how high to make their expectations as well as the long-term impact of the practices they utilize to help students meet those expectations.

\section{CONCLUSION}

When pre-service teachers are given the opportunity to grapple with the complexity of educational rhetoric, they can begin to consider whether required teaching practices align with their own equity goals, approaches to teaching and learning, and conceived roles in the teaching profession. Practical preparation can go hand in hand with critical consciousness. For example, pre-service teachers can question whether lesson plan templates that adhere to state mandates 
reflect equitable visions of planning for learning. As they consider how high to hold academic expectations, they can draw upon differing perspectives on intelligence and effort. Finally, preservice teachers can consider the social, historical, and political implications of holding teachers accountable for regularly assessing learning outcomes as well as setting "high expectations" for all students. By drawing on literature and my own teaching experiences, I have demonstrated how contextualizing the rhetoric in two required practices for state licensure can provide rich opportunities for deep, critical engagement with ideas around what teachers should do in the classroom.

Perhaps ironically, my aim in this article has been to articulate a vision for improving the practice of teacher educators. If teacher educators want pre-service teachers to deeply understand the pedagogical practices that are required of or recommended to them, they should engage in more complex investigations of practice discourse. Just as we should avoid "thin" approaches to educational equity (Cochran-Smith et al., 2016), we should avoid approaches to teacher education that are overly simplistic or narrow in scope. Instead, explorations of ideological and sociopolitical debates in education are necessary and cannot only occur in separate, social foundations classes. Pre-service teachers stand to benefit from the integration of complex perspectives into their early coursework, as they are introduced to requirements for licensure, and into their methods classes.

We cannot allow the turn toward practice in teacher education to result in generations of technician teachers focused on quick fix solutions to complex problems. Rather, teacher educators should empower pre-service teachers with robust understandings of the field, their position in it, and the larger implications of their teaching practices. By engaging in these critical discussions, teacher educators can help pre-service teachers become critical consumers of practice, focused on long-term outcomes instead of short-term outputs.

\section{REFERENCES}

Anderson, L., Krathwohl, D., Airasian, P., Cruickshank, K., Mayer, R., Pintrich, P., ... Wittrock, M. (2001). A taxonomy for learning, teaching, and assessing. Longman New York.

Anderson, L., \& Oakes, J. (2014). The truth about tracking. In Gorski, P. \& Zenkov, K. (Eds.), The big lies of school reform: Finding better solutions for the future of public education, (109-128). Routledge.

Armstrong, P. (n.d.). Bloom's taxonomy. Vanderbilt University Center for Teaching. Retrieved June 13, 2020, from https://cft.vanderbilt.edu/guides-sub-pages/blooms-taxonomy/

Ball, D. L., \& Cohen, D. K. (1999). Developing practice, developing Practitioners: Toward a practice-based theory of professional education. In G. Sykes \& L. Darling-Hammond (Eds.), Teaching as the learning profession: Handbook of policy and practice (pp. 3-32). https://doi.org/10.1037/0022-3514.90.4.644 
Ball, D. L., \& Forzani, F. M. (2009). The work of teaching and the challenge for teacher education. Journal of Teacher Education, 60(5), 497-511.

https://doi.org/10.1177/0022487109348479

Ball, D. L., \& Forzani, F. M. (2011). Building a common core for learning to teach and connecting professional learning to practice. American Educator, 35(2), 17-39.

Blumenfeld, P. C., Soloway, E., Marx, R. W., Krajcik, J. S., Guzdial, M., \& Palincsar, A. (1991). Motivating project-based learning: Sustaining the doing, supporting the learning. Educational Psychologist, 26(3-4), 369-398. https://doi.org/10.1080/00461520.1991.9653139

Boston College. (2013). Pre-Practicum 1 Syllabus. Retrieved April 10, 2020, from https://www.bc.edu/content/dam/files/schools/Isoe/pdf/Practicum_Syllabi/P1_Under grad_F13_S14.pdf

Bowman, M., \& Gottesman, I. (2017). Making the socio-historical visible: A place-conscious approach to social foundations in practice-centered teacher preparation. Teaching and Teacher Education, 68, 232-240. https://doi.org/10.1016/j.tate.2017.09.001

Bransford, J. D., Brown, A. L., \& Cocking, R. R. (2000). How people learn (Vol. 11). National Academy Press.

Chieppo, C. D., \& Gass, J. T. (2009). Accountability overboard. Education Next, 9(2), 18-26. Retrieved from https://www.educationnext.org/accountability-overboard/

Cho, J., \& Trent, A. (2005). "Backward" curriculum design and assessment: What goes around comes around, or haven't we seen this before? Taboo, 9(2), 105-123.

Cochran-Smith, M., \& Lytle, S. L. (2006). Troubling images of teaching in No Child Left Behind. Harvard Educational Review, 76(4), 668-697. https://doi.org/10.17763/haer.76.4.56v8881368215714

Cochran-Smith, M., Stern, R., Sánchez, J. G., Miller, A., Keefe, E. S., Fernández, M. B., Chang, W., Carney, M.C., Burton, S., \& Baker, M. (2016). Holding teacher preparation accountable: A review of claims and evidence. National Education Policy Center. Retrieved April 10, 2020 from https://nepc.colorado.edu/publication/teacher-prep Crawford-Garrett, K., \& Riley, K. (2019). Race and class silences in teacher education: Resisting strategy-based approaches to literacy methods instruction. Teaching Education. https://doi.org/10.1080/10476210.2018.1443065

Crowe, E. (2010). Measuring what matters: A stronger accountability model for teacher education. Center for American Progress. Retrieved from https://www.americanprogress.org/issues/education-k12/reports/2010/07/29/8066/measuring-what-matters/

Delpit, L. D. (2012). "Multiplication is for white people": Raising expectations for other people's children. The New Press.

Dewey, J. (1959). Dewey on education. Teachers College Press.

Duckworth, A. L. (2018). Grit: The power of passion and perseverance. Scribner. 
Duckworth, A. L., Peterson, C., Matthews, M. D., \& Kelly, D. R. (2007). Grit: Perseverance and passion for long-term Goals. Journal of Personality and Social Psychology, 92(6), 10871101. https://doi.org/10.1037/0022-3514.92.6.1087

Dutro, E., \& Cartun, A. (2016). Cut to the core practices: Toward visceral disruptions of binaries in practice-based teacher education. Teaching and Teacher Education, 58, 119-128. https://doi.org/10.1016/j.tate.2016.05.001

Dweck, C. (2007). Mindset: The new psychology of success. Ballantine Books.

Dweck, C. (2015, September 22). Carol Dweck revisits the "growth mindset." Education Week. https://doi.org/10.1017/CBO9781107415324.004

Edmonds, R. (1979). Effective schools for the urban poor. Educational Leadership, 37(1), 1524.

Excerpts from Bush's speech on improving education. (1999, September 3). The New York Times, p. A14. Retrieved from https://www.nytimes.com/1999/09/03/us/excerptsfrom-bush-s-speech-on-improving-education.html

File, N., Mueller, J., \& Wisneski, D. B. (2012). Curriculum in early childhood education. Routledge.

Gershenson, S., \& Papageorge, N. (2018). The power of teacher expectations: How racial bias hinders student attainment. Education Next.

Grossman, P. (Ed.). (2018). Teaching core practices in teacher education. Harvard Education Press.

Grossman, P., \& Dean, C. G. P. (2019). Negotiating a common language and shared understanding about core practices: The case of discussion. Teaching and Teacher Education, 80, 157-166. https://doi.org/10.1016/j.tate.2019.01.009

Grossman, P., Hammerness, K., \& McDonald, M. (2009). Redefining teaching, re-imagining teacher education. Teachers and Teaching: Theory and Practice, 15(2), 273-289. https://doi.org/10.1080/13540600902875340

Gutiérrez, K. D., \& Rogoff, B. (2003). Cultural ways of learning: Individual traits or repertoires of practice. Educational Researcher, 32(5), 19-25. https://doi.org/10.3102/0013189X032005019

Hallinan, M. T. (1994). Tracking: From theory to practice. Sociology of education, 67(2), 79-84. Kolodner, J. L. (1991). The Journal of the Learning Sciences: Effecting changes in education. Journal of the Learning Sciences, 1(1), 1-6. https://doi.org/10.1207/s15327809jls0101_1

Krathwohl, D. R. (2002). A revision of Bloom's Taxonomy: An overview. Theory into Practice, 41(4), 212-218. https://doi.org/https://doi.org/10.1207/s15430421tip4104_2

Kretchmar, K., \& Zeichner, K. (2016). Teacher prep 3.0: A vision for teacher education to impact social transformation. Journal of Education for Teaching, 42(4), 417-433. https://doi.org/10.1080/02607476.2016.1215550 
Lagemann, E. C. (2000). An elusive science: The troubling history of education reserach. University of Chicago Press.

Lee, C. D. (2017). Expanding visions of how people learn: The centrality of identity repertoires. Journal of the Learning Sciences, 26(3), 517-524.

https://doi.org/10.1080/10508406.2017.1336022

Lee, D. (2019). G: The miseducation of Larry P. Retrieved from https://www.wnycstudios.org/podcasts/radiolab/articles/g-miseducation-larry-p

Lemov, D. (2010). Teach like a champion: 49 techniques that put students on the path to college. John Wiley \& Sons.

Lemov, D. (2015). Teach like a champion 2.0: 62 techniques that put students on the path to college. Jossey-Bass.

Love, B. (2019). We want to do more than survive: Abolitionist teaching and the pursuit of educational freedom. Beacon Press.

Lucas, S. R. (1999). Tracking inequality: Stratification and mobility in American high schools. Teachers College Press.

Massachusetts Department of Elementary and Secondary Education. (2016). Guidelines for the Candidate Assessment of Performance. 1-36. Retrieved April 10, 2020 from http://www.doe.mass.edu/edprep/cap/guidelines.html

Massachusetts Department of Elementary and Second Education. (2019). Handbook for the Candidate Assessment of Performance. 1-99. Retrieved August 10, 2020 from http://www.doe.mass.edu/edprep/cap/guidelines.html

McDonald, M., Kazemi, E., Kelley-Petersen, M., Mikolasy, K., Thompson, J., Valencia, S. W., \& Windschitl, M. (2014). Practice makes practice: Learning to teach in teacher education. Peabody Journal of Education. https://doi.org/10.1080/0161956X.2014.938997

Michigan Department of Education. (n.d.). Core Teaching Practices. Retrieved from https://www.michigan.gov/documents/mde/Core_Teaching_Practices_648488_7.pdf

Milner IV, H. R. (2010). What does teacher education have to do with teaching? Implications for diversity studies. Journal of Teacher Education, 61(1-2), 118-131. https://doi.org/10.1177/0022487109347670

Nasir, N. S., Rosebery, A. S., Warren, B., \& Lee, C. D. (2014). Learning as a cultural process: Achieving equity through diversity. In K. Sawyer (Ed.), The Cambridge Handbook of the Learning Sciences, Second Edition (pp. 686-706). https://doi.org/10.1017/CBO9781139519526.041

Nasir, N. S., Scott, J., Trujillo, T., \& Hernandez, L. (2016). The sociopolitical context of teaching. In D. H. Gitomer \& C. A. Bell (Eds.), Handbook of Research on Teaching (pp. 349-390). https://doi.org/10.3102/978-0-935302-48-6_5

Next Generation Science Standards. (2016). Using phenomena in NGSS-designed lessons and units. Retrieved from https://www.nextgenscience.org/sites/default/files/Using Phenomena in NGSS.pdf 
Nieto, S. (2000). Placing equity front and center some thoughts on transforming teacher education for a new century. Journal of Teacher Education, 51(3), 180-187. https://doi.org/10.1177/0022487100051003004

Nieto, S. (2010). Racism, discrimination and expectations of students' achievement. In A. S. Canestrari \& B. A. Marlowe (Eds.), Educational foundations: An anthology of critical readings ( $2^{\text {nd }}$ edition). Sage.

Oakes, J. (2005). Keeping track ( $2^{\text {nd }}$ edition). Yale University Press.

Peltier, G. L., \& Noonan, D. W. (2003). Influential publications in education 1950-2002. The Clearing House: A Journal of Educational Strategies, Issues and Ideas. https://doi.org/10.1080/00098650309602007

Philip, T. M., Souto-Manning, M., Anderson, L., Horn, I., J. Carter Andrews, D., Stillman, J., \& Varghese, M. (2019). Making justice peripheral by constructing practice as "core": How the increasing prominence of core practices challenges teacher education. Journal of Teacher Education, 70(3), 251-264. https://doi.org/10.1177/0022487118798324

Sawyer, K. (2014). Introduction: The new science of learning. In K. Sawyer (Ed.), The Cambridge Handbook of the Learning Sciences (pp. 1-18). Cambridge University Press.

Schneider, J. (2014). From the ivory tower to the schoolhouse. Harvard Education Press.

Schneider, R. M., Krajcik, J., Marx, R. W., \& Soloway, E. (2002). Performance of students in project-based science classrooms on a national measure of science achievement. Journal of Research in Science Teaching, 39(5), 410-422. https://doi.org/10.1002/tea.10029

Sfard, A., \& Prusak, A. (2005). Identity that makes a difference: Substantial learning as closing the gap between actual and designated identities. Proceedings of the 29th Conference of the International Group for the Psychology of Mathematics Education.

Sheth, M. J. (2018). Grappling with racism as foundational practice of science teaching. Science Education, 103(1), 37-60. https://doi.org/10.1002/sce.21450

Singer, J., Marx, R. W., Krajcik, J., \& Chambers, J. C. (2000). Constructing extended inquiry projects: Curriculum materials for science education reform. Educational Psychologist, 35(3), 165-178. https://doi.org/10.1207/S15326985EP3503_3

Sleeter, C. E. (2008). Preparing White teachers for diverse students. In Marilyn Cochran-Smith, S. Feimen-Nemser, J. McIntyre, \& K. Demers (Eds.), Handbook of Research on Teacher Education (pp. 559-582). American Educational Research Association.

Sposato Graduate School of Education. (n.d.). Curriculum. Retrieved from https://www.sposatogse.org/about/curriculum

Strauss, V. (2016, May 10). The problem with teaching "grit" to poor kids? They already have it. Here's what they really need. The Washington Post. Retrieved from https://www.washingtonpost.com/news/answer-sheet/wp/2016/05/10/the-problemwith-teaching-grit-to-poor-kids-they-already-have-it-heres-what-they-really-need/ 
TeachingWorks. (n.d.). High-Leverage Practices. Retrieved from http://www.teachingworks.org/work-of-teaching/high-leverage-practices

Thompson, J., Windschitl, M., \& Braaten, M. (2013). Developing a theory of ambitious earlycareer teacher practice. American Educational Research Journal. https://doi.org/10.3102/0002831213476334

Tyler, R. W. (1949). Basic principles of curriculum and instruction. University of Chicago Press. U.S. News \& World Report. (2020). Pre-K - 12 Rankings. Retrieved from https://www.usnews.com/news/best-states/rankings/education/prek-12

Watanabe, M. (2008). Tracking in the era of high stakes state accountability reform: Case studies of classroom instruction in North Carolina. Teachers College Record, 110(3), 489-534.

Wiggins, G. P., \& McTighe, J. (2005). Understanding by Design. ACSD.

Windschitl, M., Thompson, J., Braaten, M., \& Stroupe, D. (2012). Proposing a core set of instructional practices and tools for teachers of science. Science Education, 96(5), 878903. https://doi.org/10.1002/sce.21027

Wong, A. (2016). What are Massachusetts public schools doing right? The Atlantic. Retrieved from https://www.theatlantic.com/education/archive/2016/05/what-aremassachusetts-public-schools-doing-right/483935/

Yoon, S. A., \& Hmelo-Silver, C. E. (2017). What do learning scientists do? A survey of the ISLS membership. Journal of the Learning Sciences, 26(2), 167-183. https://doi.org/10.1080/10508406.2017.1279546

Zeichner, K. (2012). The turn once again toward practice-based teacher education. Journal of Teacher Education, 63(5), 376-382. https://doi.org/10.1177/0022487112445789

Zeichner, K. (2016). Advancing social justice and democracy in teacher education: Teacher preparation 1.0, 2.0, and 3.0. Kappa Delta Pi Record, 52(4), 150-155.

https://doi.org/10.1080/00228958.2016.1223986 